\title{
Frictional Encounters in Postwar Human Rights: An Analysis of LGBTQI Movement Activism in Lebanon
}

The advancement of LGBTQI rights is now a significant component of many international aid programmes. The successful diffusion of LGBTQI rights is supposed to rest on a successful interaction between international agencies that foster global rights and social movement actors that embed these processes at the local level. Yet, these encounters between global human rights ideas and local practices may not always generate positive dynamics. Drawing on the concept of 'friction' - the unstable qualities of interaction between global and local forces - this paper explores the relationship between international actors promoting LGBTQI rights and local social movement activists in postconflict societies. I argue that the notion of global rights is particularly problematic in the context of post-conflict societies where rights are allocated on the basis of sectarian identity. To empirically illustrate these issues, I look at LGBTQI social movement activism in the divided society of Lebanon. In particular, I examine the emergence and development of Helem - the first recognised LGBTQI rights group in the Middle East and North Africa - which quickly became the poster child for international development and aid agencies in the Global North. 


\section{Introduction}

In a number of states around the world sexual minorities, notes the United Nations, experience 'killings, rape and physical attacks, torture, arbitrary detention, the denial of rights to assembly, expression and information, and discrimination in employment, health and education'. ${ }^{1}$ In October 2015 , the UN in a statement called on states to act urgently to end violence and discrimination against lesbian, gay, bisexual, transgender, Queer/Questioning and Intersex (LGBTQI) adults, adolescents and children. The UN declared that 'Human rights are universal - cultural, religious and moral practices and beliefs and social attitudes cannot be invoked to justify human rights violations against any group, including LGBTI [Lesbian Gay Bisexual Transgender Intersex] persons'. ${ }^{2}$ Running parallel to these demands, the promotion of LGBTQI rights has increasingly become a significant component of international development programmes. Leading aid agencies incorporate LGBTQI rights into their institutional mission and underwrite core policies supporting rights diffusion and sexual equality in places where sexual minorities experience oppression and violence. LGBTQI movements and activists in developing countries are identified by agencies for funding so that they can oppose homophobia and provide support services for a vulnerable sexual minority population. In consequence, while sexual minorities were once marginalised in development programmes, the recent attention to and funding for LGBTQI within international development programming represents a 'Queering' of human rights. ${ }^{3}$

The efficacy of approaches to the diffusion of LGBTQI rights therefore rests on a productive interaction between the global and the local, between international development agencies and human rights groups that foster global norms, on the one hand, and social movement actors that receive and embed these processes at the local level on the other. Global processes, as Tsing reminds us, can only be charged and enacted though practical encounters at the local level. ${ }^{4}$ For Merry, human rights social movement activists working at 
the local scale 'vernacularise' - translate the 'transnational metacode of human rights to local situations' - so as to achieve policy and attitudinal change..$^{5}$ Thus, for example, the repeal of Uganda's Anti-Homosexuality Act has been identified as the outcome of the 'close working relationship between international actors and national civil society'. ${ }^{6}$

Yet, these encounters between global and local actors, human rights ideas and practices may not always generate predetermined, predictable and positive dynamics. Scholars increasingly illuminate the uneven, unequal, unexpected and uncertain processes and outcomes that occur as a product of global and local interactions in human rights. These meetings and collisions 'can be both a site for empowerment and for domination' for local activists and populations. ${ }^{7}$ A variety of conceptual frameworks are deployed to capture these complex forces. Merry notes that social movement activists may either 'replicate', 'hybridise' or 'subvert' global human rights norms. ${ }^{8}$ Tsing, similarly, has coined the concept of 'friction': the 'awkward, unequal, unstable, and creative qualities' of global interaction'. Applying friction to the consequences of international peacebuilding programmes, Björkdahl and Höglund note a range of responses by local actors 'which arise as a result of meetings between actors, ideas and practice in global - local relationships', and include 'compliance, adoption, adaptation, co-option, resistance and rejection'. ${ }^{10}$

Research on frictionality tends to view such engagements as leading to a singular form of movement response. That is, local human rights movements may either decide on compliance, adoption, adaptation, co-option, resistance and rejection in relation to global rights. Yet, the full array of these strategic options may uneasily coincide within the same movement. Activists can contentiously divide as whether to align the movement to the global human rights framework or pursue instead a more radical form of opposition to what they perceive as limiting rights-based discourse that does not resonate with the local environment 
the movement operates within. Global rights norms and discourses can generate intramovement acrimony and splits.

In this paper I explore how this multiple form of frictionality can be the result of LGBTQI rights activism in societies that are have experienced sectarianised civil war and political violence. In such societies, postwar political and public institutions aim to accommodate the identities of the respective ethnic or ethnoreligious groups. ${ }^{11}$ These sectarian systems are characterised by path dependent features that resist any attempt by nonsectarian groups aiming to achieve policy reform. ${ }^{12}$ Non-sectarian movements, such as LGBTQI movements, confront deeply entrenched structural and agential barriers that stymie their capacity to realise objectives ${ }^{13}$. In addition, the weak state and dysfunctional structure of postwar sectarian systems affords little opportunities for movements advancing rights and policy change, especially as informal rather than formal institutions predominate and sectarian interests are almost exclusively accommodated within these structures.

In the context of such structures which provide limited room for movements to manoeuvre, activists confront a number of tactical and strategic dilemmas regarding how to achieve rights and socio-political change. In other words, since the formal sectarian institutions of the state are closed to the LGBTQI movement, movement members debate and diverge on whether to 'upscale' or 'downscale' their activism. 'Upscale' refers to the process through which movements seek to go above state institutions by engaging with powerful international actors who activists hope will use their leverage to effect rights. 'Downscale', alternatively, denotes how activists circumvent formal institutions by instead working within informal institutions and channels at the local level. This scale also involves activists seeking to confront and render inoperable homophobic institutions and practices. This 'downscaling' can also include radical expressions activism that purposely seeks to confront and eradicate sectarian institutions that are identified as reproducing homophobia and patriarchy. 
In addressing these issues, I look at LGBTQI social movement activism in postwar Lebanon. In particular I examine the emergence and development of Helem - the first recognised LGBTQI rights group in the Middle East and North Africa - which quickly became the poster child for international development and aid agencies from the Global North. ${ }^{14}$ I focus on the frictional outcomes that occur within Lebanon's LGBTQI movements as activists generate differing methods and tactics for pursuing rights.

While it is important to record the immense challenges for non-sectarian movements in Lebanon, in this paper I also trace the complex, multiple and important ways in which the Lebanese LGBTQI movement create changes. I argue that it is necessary to broaden our understanding of social movement impacts in Lebanon from the policy domain to also include the process through which movements render sectarian power inoperative and their capacity to foment wider attitudinal transformation which contradict sectarian hegemony. This process of capturing social movement impacts requires us to also uncover the backstage, unofficial work of movements whose activism functions through securing relatively unofficial, de jure rather than de facto forms of rights from key agencies and actors which risk being conditional and easily revocable. In particular, given the weak and dysfunctional state structure that characterises the sectarian system, I argue that non-sectarian movements effect change by operating within informal institutions or where the state is not always strongly present.

The research for this paper comprises five fieldwork phases in Lebanon (September 2012, July 2014, June 2015, January 2016, October 2017). A constructivist epistemology was utilised for interviewing Lebanese LGBTQI activists (N-30) and an interpretative framework for analysing them. In the constructivist epistemology, the object of qualitative research is to understand that knowledge is gained through the social constructions of the individuals we research. The interpretative framework does not outline testable hypotheses, but instead 
focuses on understanding the social context in which humans make sense of their subjective reality and attach meaning to it as the situation develops. Given that LGBTQI activists continue to experience various forms of state harassment and persecution, all respondents remain anonymous in this paper.

\section{Developing LGBTQI Rights in Postwar Societies}

While scholars and policymakers recognise the profoundly gendered impacts of contemporary civil war and peace processes, these effects are rarely considered in relation to LGBTQI populations. Yet sexual minorities are specifically targeted during conflict. The harrowing plight of Syria's LGBTQI members in the civil war is well documented by human rights groups. ${ }^{15}$ 'Corrective violence' or social cleansing featured as a strategy against sexual minorities Colombia deemed as failing to conform to traditional gender stereotypes. ${ }^{16}$ AntiLGBTQI violence is common to societies emerging from conflict, including in Uganda, Northern Ireland, South Africa, Bosnia, and Lebanon. From the use of corrective rape against lesbians in post-apartheid South Africa to the targeting of gay and lesbian people in postAgreement Northern Ireland, attacks against LGBTQI people are pervasive in peace process societies. ${ }^{17}$ LGBTQI individuals and communities are often targeted in fragile postwar societies in which violence between the formerly warring communities is no longer acceptable and, as such, can easily become submerged in more politically allowable forms of discrimination.

In order to understand the status of Lebanon's LGBTQI population it is necessary to detail the character of the state's postwar sectarian institutional structures. Lebanon's civil war, which began in 1975 and ended in 1990, is often simplistically framed as ethnoreligious - between Christian and Muslim sects - it was extremely complex and involved a succession of conflicts involving multiple internal and external actors and states. ${ }^{18}$ However, the war 
had a hardening effect on sectarian identities, a process that was exacerbated by 'mass displacement, wide-scale killing, rape, torture, arbitrary detention, and enforced disappearances'. ${ }^{19}$ The warlords sought to destroy 'all memories of coexistence and common interests between the Lebanese' ${ }^{20}$

The war expedited rounds of ethnic cleansing and it produced new powerful sectarian political networks. In the absence of a functioning state, the warlords nurtured forms of governance that covered their sectarian fiefdoms. The sectarian militias constructed their own spheres of civil society to distribute a wide portfolio of services for the communities they claimed to defend. Practically everything - ranging from medical care, schooling and universities, refuse and postal collection, the supply of gas and electricity, and even childcare - became subject to the purview of the sectarian militias. By providing basic services, the militias exploited the situation to extend jurisdictional and coercive control over their war weary communities.

The civil war officially ended with the Ta'if Peace Agreement in 1989. In essence, the Agreement formalised the sectarian structures established during the war. Ta'if's title - 'no victor and no vanquished' - signified that peace is achieved by creating an institutional apparatus that ensured no group could dominate the state. ${ }^{21}$ The key institutional mechanism to freeze the balance of power between the main groups was power-sharing. In this system, all of the salient sectarian groups are guaranteed representative power in government and across the public sector based on their presumed demographic size. Post-war Lebanese elections have led to 'hardening, rather than ameliorating, sectarian cleavages'. ${ }^{22} \mathrm{As}$ Cammett puts it: 'The allocation of government posts by sect combined with the electoral system constitute and perpetuate sectarianism as the foundation of politics' ${ }^{23}$

The process of maintaining the balance of power between groups percolates into all aspects of state and society relations. The principle of the allotment state ("muhassa al- 
dawla') means that the respective sectarian elites - often former warlords - are granted control of major public offices, which they utilise as both instruments for personal enrichment and as a resource for clientelism within their own sectarian networks. ${ }^{24}$ At the same time, endemic state weaknesses are deliberately maintained by sectarian elites so that goods and services are placed under their administrative networks. These social welfare services - especially healthcare and education - are used to ensure that much of the workingclass population are heavily reliant on the assistance provided by their communal leaders. As Bauman explains, 'the political economy of sectarianism is one where a small politically connected elite appropriates the bulk of economic surplus and redistributes it through communal clientelism'. ${ }^{25}$ Thus, the 'post-war neoliberal state retrenchment compels the economically underprivileged to seek sectarian patronage for a range of social services' ${ }^{26}$

The sectarian system further imprints itself in a deeply personal way on all Lebanese citizens. Lebanon's constitution enshrines a 'covenant of mutual coexistence' between the groups. In this, groups are proscribed from interfering in the internal affairs of their neighbouring sects. Under the terms of segmental autonomy, the constitution devolves legal authority to the religious leaders of the groups over a range of personal matters, including marriage, divorce and child custody rights. These personal status laws not only serve to mark all Lebanese as sectarian subjects rather than equal citizens; they reinforce inequalities between men and women across sects. Civil marriage - marriage between members of different sects - is prohibited as it threatens the delicate demographic boundaries that delineate sectarian groups imagined as reified and bounded communities.

\section{Sexuality and Gender}

Lebanon's sectarian system is deeply intertwined with gender and sexuality. As noted above, in order to maintain communal boundaries between groups, the Lebanese legal system - 
enshrined in Article 9 of the constitution - is characterised by legal pluralism, which in effect grants a high degree of autonomy to the 18 formally recognised sects over their internal matters, especially in religion and schooling. The sects follow 15 separate laws regulating the personal status of their members, and each sect receives state funding to operate its own religious courts to adjudicate cases related to marriage, divorce, custody of children, and inheritance. $^{27}$

These personal status laws that uphold the sectarian framework act to reproduce patriarchy and homophobia. In connection to gender, the personal status laws sustain inequalities between women and men; for example, all confessions allow girls to marry at a younger age than boys, women are prohibited to pass their nationality to their children, it is much more difficult for women to obtain a divorce compared to men, and marital rape and other forms of domestic violence have been sanctioned. The status laws, furthermore, entrench cleavages and disparities among women with women in some sects receiving better conditions than others. Sexuality is also regulated by the sectarian apparatus. Law 534 of the Penal Code, which is used to enforce the status laws, criminalises sex deemed as 'unnatural', is directed at the LGBTQI population, and it carries a minimum one-year jail sentence. ${ }^{28}$ Expressions of non-conforming gender identity is further prosecuted under several other articles regulating public morality.

The interweaving of the sectarian system with gender and sexuality illuminates how women and sexual minorities are positioned as boundary markers of ethnic and nationalist projects. While women's roles in such movements are often exalted as biological producers of members of ethnic collectivities, sexuality - especially supposedly non-reproductive groups like lesbianism and homosexuality - is framed as damaging the health of the ethnie. For example, the control of women's sexuality is seen as a security issue in Lebanon. Since the premise of civil peace is framed as one in which boundaries between groups are frozen, 
the right of a woman to pass on her nationality to her children is denied because it is claimed that women will then be able to marry men from different communities and risk changing the demographic equilibrium of the Lebanese state, thus undermining the sectarian system. ${ }^{29}$

In response to their unequal status, major LGBTQI movements have emerged to challenge discrimination, inequality and, in consequence, the operating logic of the state's sectarian arrangements. Lebanon's LGBTQI activism provides an important example of the constrained forms of change that movements stimulate despite the existence of major impediments.

\section{Helem and LGBTQI Activism}

LGBTQI activism in Lebanon emerged through Helem, the first above ground LGBTQI social movement in the Middle East and North Africa. Helem ${ }^{30}$ began in the late 1990 s as an underground on-line movement called Club Free. In 2004, a small number of activists formed Helem as a publically open 'rights-based organization that focuses on advocating and lobbying for the legal and social rights of people with alternative sexuality'. ${ }^{31}$ Helem campaigned to end the criminalisation of, stigmatisation and discrimination against LGBTQI individuals. Helem, as a leading activist explained, 'brings together all of these activists under one roof from different confessional backgrounds, different economic backgrounds, educational backgrounds' ${ }^{32}$

As a rights-based movement Helem's ability to generate policy reform is severely bounded. The state refuses to officially acknowledge the existence of LGBTQI organisations. In 2004 Helem - as all Lebanese civil society organisations are required to do - submitted a formal notification of its existence to the Ministry of the Interior, who as per custom then registers groups to allow them to set up a bank account to access funding from donors. Although the Ministry of the Interior never officially rejected the application, it labelled 
Helem as 'shameful' and shelved the application. In addition, Lebanese sexual minorities confront 'discrimination in employment and arbitrary dismissal, to limited access to housing, health, and social services, to political and financial extortion' ${ }^{33}$ A report commissioned by Helem activists noted that the LGBTQI community are 'periodically arrested, detained, and tortured by Lebanese security forces, while incidents of societal and family-based discrimination have not abated'. ${ }^{34}$

The Lebanese LGBTQI movement also fragmentised. In 2007, a number of women known as 'Helem Girls' - left Helem to set up Meem, an underground collective of feminists. An ideological cleavage also emerged between activists who positioned Helem as a movement positioned within the political left that seeks to confront the sectarian apparatus and activists who wish to forge a more moderate rights-based NGO. The net effect of this is that LGBTQI activism is currently split into a number of different NGOs or movements. The various NGOs, including Helem, Mosaic, the Arab Foundation for Freedoms and Equality and Pride Lebanon, work on various advocacy projects funded by various human rights and international development organisations. The radical activists, alternatively, have formed underground networks that refuse to accept aid from external funders. Thus, rather than present Lebanese LGBTQI activism as speaking with a homogenous voice, in this paper I acknowledge the multiplicity of positionings and tactics advanced by activists.

\section{Global Frictions}

As the first public LGBTQI movement in the MENA region, Helem immediately confronted a fundamental issue before they could advance rights activism: how to construct a unified movement. This strategy relies upon the theory that since rights cannot be granted without the existence of a priori community, it is necessary for activists to forge a collective public identity. The capacity to project a homogenous and fixed group identity is vital for rights- 
based movements as it enables them to foster internal solidarity, stimulate pride, forge networks, project external power, and more crucially, the ability to demand rights in the name of the group. ${ }^{35}$ Indeed, 'ambiguous, fluid identities don't fly in the political world or in courts of law' ${ }^{36}$. A Helem activist explained: 'In order for there to be rights there has to be a community' ${ }^{37}$

Researchers and activists note the lack of a cohesive LGBTQI community in Lebanon. Thus, LGBTQI individuals do not necessarily 'express any particular group solidarity . . . based on a perceived common sexuality or one informed by a mutually embraced political cause'. ${ }^{38}$ An LGBTQI activist explained to me: 'it is very difficult or me to conceive of a LGBTQI community in Lebanon much less a LGBTQI movement'. ${ }^{39}$ Many of the visible signs of a LGBTQI community are conspicuously absent in Lebanon; an activist note: 'acceptance isn't at the point where you create gay enclaves or you have a gay part of town. Something like that hasn't materialised'. ${ }^{40}$

To be sure, this situation is largely a consequence of the criminalisation of homosexuality in Lebanon and the sense of public shame that is associated with nonconforming sexuality. In response, a group of core activists seek to create collective consciousness and pride among sexual minorities. Towards this objective activists in Lebanon initially positioned the movement within the global LGBTQI movement. This is identified as a 'globalizing ... gay community and political identity struggling for equality'. ${ }^{41}$ Indicative of an emergent global subculture, the LGBTQI social movement is 'where members of particular groups have more in common across national and continental boundaries' than with those from within their own countries. This movement has 'helped create an international gay/lesbian identity $\ldots$ by no means confined to the western world' ${ }^{42}$

Helem linked itself to the global LGBTQI movement in order to provide the LGBTQI population a sense of collective identity. In 2003, the group made its first public appearance 
by unfurling the Rainbow International flag during a public protest against the coalition's occupation of Iraq. By emphasising a universal expression of LGBTQI communal identity, Helem secured resources - economic and diplomatic - offered by international human rights groups to campaign for the decriminalisation of homosexuality. For example, Helem was given an award for its human rights activism by the International Gay and Lesbian Human Rights Commission (IGLHRC). As part of this, Helem followed a strategy of visibility - a core strategy of LGBTQI rights groups in the Global North - including a campaign of public outing and pride for movement members, such as public events to mark the International Day Against Homophobia. In 2017, a number of activists attempted to organise Beirut's first Pride celebration.

In a sectarian system that reserves rights for ethnoreligious groups, non-sectarian movements demanding rights recognition often need to 'upscale' their mobilisation strategies. ${ }^{43}$ Groups appeal to international and transnational actors to pressurise the Lebanese state to address human rights. Indeed, as Ayoub argues, the transnational networks of LGBTQI advocacy organisations can have a positive effect on policy diffusion to new states. ${ }^{44}$ More particularly, Lebanese LGBTQI groups engage with sympathetic embassies and diplomatic missions to use whatever leverage and power they may have to advance LGBTQI rights with key Lebanese state actors and policymakers. Helem has also been funded by the World Bank, the World Health Organization, and the United Nations. A Helem activist noted, 'western donors are pushing policy, policy and engagement ${ }^{45}$ with the government.

Helem's role as an actor in the global LGBTQI movement thus necessitated the alignment of the movement's identity with the rubric of a universal and homogenous homosexual subject. This provided Helem with an instrument to try and convert a rather loose and unconnected non-heterosexual body of individuals into a strong sense of groupness. 
Such community activism can be developed by learning from the global LGBT movement, especially from the Global North. A Helem activist argued:

In order for there to be rights there has to be a community ... The good thing about those enclaves in the United States, in Europe, is that you can have a lot of gay people move into a neighbourhood. Some people open up a barber shop, some people open up a supermarket, some open whatever, and all of a sudden you have a community that satisfies the needs more or less. And it thrives and it grows. ${ }^{46}$

Helem's engagement with global activism thus provides two key mechanisms for the movement. First, it provides the movement with a sense of identity in order to help foster an expression of collective community and pride among members. This community consciousness building provides the basis for demanding rights. Second, it enabled the movement to upscale their activism by courting powerful international actors to wield their leverage against local Lebanese political elites. Yet, despite the vital support networks afforded to it, Helem's activists quickly viewed the movement as an anomalous presence in the global LGBTQI movement.

First, a number of Helm's activists believed there was a misalignment between Helem's local activism and the concept of the global LGBTQI movement. For a former executive director, the notion of a global LGBTQI movement is something of a misnomer given that it is dominated by activists in the Global North: 'The international movement is not international ... Maybe there is some power in the movement in Latin America, but other than that it's the Global North. Even in the Global North, economic questions are important to sexual minorities but they are downplayed by the demand for civil rights' ${ }^{47}$ More acutely, the objectives of activists in the Global North - such as recognition for same-sex marriage and adoption rights - lack saliency with the issues that confront the LGBTQI population in Lebanon, such as criminalisation, state harassment and violence. A Helem activist explained: 
you have a lot of activists coming from abroad and they have a lack of sensitivity to the specificities of Lebanon ... we are not closing the doors to international collaboration. We need funders who realise the specific situation in this region. They say 'we have gay marriage so you should have gay marriage'. We do not even have civil marriage, so why are you talking about gay marriage to us? ${ }^{48}$

Another Helem activist stated: 'this concept of gay nationalism for us is misleading ... We are not trying to import models and then implement them here, we are trying to create our own struggles We don't want to be part of this big global ghetto' ${ }^{49}$

Second, Helem was critiqued for being 'Gay Internationalist Missionaries', a group seeking to impose essentially 'Western' notions of universal homosexual identity and homophobia into the Middle East. This critique was outlined by the academic Joseph Massad, who argued that Helem reproduced the discursive identity categories of homosexual/nonhomosexuality that defines the Western sexual subject. The universal homosexual identity, claimed Massad, could not be easily imported into Arab societies, since the binary of homosexuality/heterosexuality is a product of Western modernity and does not belong to precolonial Arab culture. Massad drew a distinction between Western homosexuality and Arab same-sex desires, with the former being 'an identity that seeks social community and political rights, while the other is one of many forms of sexual intimacy that seeks corporeal pleasure' ${ }^{50}$

Third, the abundance of foreign donors supporting LGBTQI movements in Lebanon has led, in part, led to the proliferation of professionalised civil society organisations each providing niche services for the LGBTQI community. A number of LGBTQI NGOs in Lebanon have forged a network in which activists meet once a month to ensure that they do not duplicate applications for funding. The net effect of the increase of LGBTQI project funders has expedited a situation in which LGBTQI groups are primarily directed towards 
working on projects that have clearly defined goals and primarily include service provision. For example, one activist explained that 'we have an emphasis in service provision and capacity building' ${ }^{51}$ An activist from another group explained 'we are working on issues to do with torture, child protections, human rights, HIV testing, mental health'. Another noted: 'we are trying to empower LGBTQI people from local regions, tackling LGBTQI health or tackling advocacy'. ${ }^{52}$ Other NGOs, for example, work on helping Syrian LGBTQI refugees. Beyond this, LGBTQI organisations have held LGBTQI film series in various European embassies, and activists have organised IDAHO/IDAHOT weeks, an annual celebration of sexual and gender diversities, which has, in part, been supported by international agencies. These dynamics appear to fit into what is called 'NGOisation', the process in which the radical and confrontational potential of civil society is exchanged for the service provision. Thus, rather than seek to create a movement that confronts the state, for many activists, LGBTQI activism risks reproducing the very logic of the clientelistic framework that undergirds the sectarian system. While no LGBTQI NGO is a client of any of the main sectarian parties, they receive resources from international human rights groups. A former executive director of Helem argued:

Our movement is sectarian in the sense that it is part of the clientelistic system. The movement is sucked into the clientelistic system and it has an impact from funding and donors and they are a very big factor in what happens ... The radical aspect of civil society has been shut down. I think that it has been co-opted by the system. It's the Lebanese system, it's not just the government, the administration, it's not just the warlords and elites; it's the actual nature of the state. ${ }^{53}$

Fifth, the NGOisation of activism generated a split along gender lines. In 2007, a group of women activists within Helem, known as 'Helem Girls,' became frustrated with what they saw as a male dominated movement that made LGBTQI rights its strategic goal. An LGBTQI 
activist explained that the split between gay men and lesbian women partially stems from the inability of men to comprehend the specific nature of oppression that lesbians confront:

\footnotetext{
I don't think that gay men understand that lesbians are women, and women already in the Middle East have to deal with a lot more. Second, lesbian women also feel that they don't have enough voice, or that they don't have enough representation and unfortunately it translates into a zero-sum game, where we can't have a NGO that has everyone together, so let's have a lesbian NGO. ${ }^{54}$
}

The frustration of women activists led to Helem Girls forming their own movement called 'Meem.' Formed in 2008, Meem was set up to engage in feminist and queer politics, which refused to articulate fixed identity-based approaches to gender and sexuality. Meem described itself as a 'social justice movement' that mobilises to contest the existence of oppression against gay women and bisexuals by targeting political sectarianism. ${ }^{55}$ Although Meem is no longer active, in comparison to gay men, a Helem activist noted:

\footnotetext{
a lot of queer women's movements are a lot more active [than men] because as women they are much more discriminated against as women and as lesbians, because of the way that the system is, because of domestic violence, the right to give your children nationality, because of misogyny across the board.$^{56}$
}

\section{Localised engagements}

The previous section outlined how internationalisation of the Lebanese LGBTQI movement generated various frictional dynamics for activists. In response, a number of activists seek to connect the movement connect more strongly with the local exigencies of Lebanon. Activists begin this project by conceptualising how Lebanon's sectarian system reproduces itself in terms of regulating sexuality, promoting homophobia and patriarchy. For example, a feminist activist explained that the fundamental basis for creating a unified women's movement in 
Lebanon is to facilitate an understanding how the sectarian system subjugates women by dividing their interests along ethnoreligious lines:

\footnotetext{
The sectarian system divides our cause and makes it impossible for us to co-operate together because if I want to work with Shia women, we don't have same demands, we don't ask for the same thing, and we don't ask it from the same institution. If I want to work for them I have to work with the religious courts, but because I am not a Shia they will laugh at us and say you are coming to democratise our culture. They split our cause and it is very hard to remind women that we all have the same cause. They are dividing our cause and it is so hard to mobilise. ${ }^{57}$
}

More broadly, activists work to illuminate how the sectarian system purposely discourages non-sectarian movements from advancing political claims. As noted by a leading Helem activist:

\footnotetext{
The sectarian system in Lebanon is designed in a way with which to make it incredibly hard for change to happen and that renders it intrinsically homophobic, racist and sectarian. The way that the system is entrenched has legitimised sectarianism in the minds of the Lebanese public as something legitimate, as matter of fact, that it exists, so it has unfortunately made a lot of mobilisation for a lot of causes very problematic simply because it's a very easy card for a lot Lebanese decision maker to play with which to exonerate their own positions and with which to excuse their own mistakes, with which to rally support. $^{58}$
}

In this way, LGBTQI activists note the closed nature of the sectarian system, in which it is not possible for movements to pursue LGBTQI rights claims through official state institutions. A former executive director of Helem explained:

The sectarian system has always been opposed to us. Even if you want to go inside the institutions as an LGBT movement, you can't. You can't run for elections to get to parliament or link up with one of 
the militias or one of the parties. These parties are still very homophobic, on the question of sexuality. The formal process is closed to LGBT activism. ${ }^{59}$

A document by the Meem, a feminist collective, asked:

$[\mathrm{H}]$ ow does one advocate for gay rights in Lebanon? Suppose the government did want to expand gay rights, how would they even do that? Any effort to reform laws and practices towards expansion of gay rights would have to negotiate independently with each religious community because $\ldots$ any major political development in Lebanon requires the support of all the various sects. ${ }^{60}$

Lebanon's LGBTQI movement recognises the difficulties of pursuing rights within the formal institutions of the state. In the absence of formal political opportunity structures, LGBTQI activism is crafted to deal with the local environment. As such, this activism operates backstage to create informal relationships, understandings and procedures with various key actors. In the context of LGBTQI movements having an extremely limited access to the formal governance and policy institutions, some activists devise ways to manoeuvre around the system. For example, some groups have overcome the ban on LGBTQI organisations receiving official Ministry of the Interior notification. One group received the official permit by submitting an application that made no mention of sexuality and instead emphasised the organisation's role in spreading democracy, supporting human rights, building social and economic infrastructure, and empowering society. A leading activist explained:

We played on the way to get registered. We play with the words on the application because we know if you mention 'LGBT' you will not get a permit. We can open up a bank account and everybody knows that we are LGBT. We get into the system the Lebanese way. We turn it around. ${ }^{61}$ 
Helem's activism seeks to make homophobic institutions and practices inoperative. This requires activists to work through back channels and informal institutions. Helem's activism engages with figures that oversee and implement discriminatory and oppressive acts against the LGBTQI population. An activist stated:

\footnotetext{
We empower people connected to the LGBT population, such as lawyers, doctors, psychologists, so that they know how to deal with the LGBT population. In this way we build connections with the wider society to provide knowledge so that they can deal with the LGBT community in a professional manner. ${ }^{62}$
}

This activism recognises that Lebanon's informal institutions or practices provide the main arena of engagement and contestation. A leading Helem activist argued that the movement is required to confront:

The reality that is here in Lebanon, the system here, and the way it works, the relationships and the mechanisms that make it operate ... rather than a state based on administration and laws, it's based on connections and craftiness. ${ }^{63}$

An important example is Helem's strategic approach to Law 534. Although the movement publically lists decriminalisation of homosexuality as a fundamental objective, an activist stated: 'our main goal is to end 534; however this is not going to happen anytime soon. I can't imagine in my lifetime the Lebanese parliament sitting and discussing whether they should keep or remove Law 534' ${ }^{64}$ Instead of pursuing policy reform, Helem utilises tactics to render 534 largely inoperable at the point of prosecution. This activism aims for de facto rather than de jure decriminalisation. Towards this, LGBTQI activists have lobbied a number of Lebanon's judges not to apply Law 534 in court due to the ambiguous legal basis of 
'nature' that is used to prosecute the LGBTQI population. Since 2007, four court rulings have declared that 534 cannot be used to convict LGBTQI individuals.

The essentially informal understandings and relationships that have led to the inoperability of 534 engender forms of change that are provisional, reversible and subject to new forms of oppression and backlash. Despite few judges applying 534 for sentencing, since 2012 there has been an increase in numbers of individuals arrested by the Internal Security Forces (ISF) on the basis of 534 or public nuisance laws. In many cases, individuals especially members of the trans community - are arrested solely on their appearance or mannerisms without evidence of any sexual act. A former Helem executive director explained that the 'moral police' - the security forces - 'still try to police sexuality in other ways; they arrest people under public nuisance laws'. ${ }^{65}$

Arrestees are often illegally detained, subject to torture and even sexual violence. Thus, 'relying on the law is really futile because it's not about law 534, most of the cases that get to the courthouse are finally thrown out'. ${ }^{66}$ Instead, as an activist explained:

\footnotetext{
It's about the ISF security officer suspecting that someone is gay and then arresting them based on that suspicion, and then going illegally through their phone and their personal belongings to find any sort of damning evidence. When they do, they of course arrest everyone else they can find using these mechanisms and then what you have is the systematic use of torture and adaptive torture whereby they learn what works and doesn't work. ${ }^{67}$
}

A notable technique used by the ISF is anal examinations supposedly to determine suspects' sexual behaviour. On one occasion in 2012, a raid carried out by the ISF on a cinema in Beirut led to the arrests of 36 men, all of whom were detained by the Morals Protection Bureau and subject to anal probes by forensic doctors. Similar to its work with judges on 534, Helem's activism to deactivate anal examinations involves securing largely informal 
understandings and procedures from key agencies. In particular, lobbying within the Lebanese Doctor's Syndicate led to its head to ban doctors from carrying out anal examinations on the basis that they are medically and scientifically useless in determining whether consensual anal sex has taken place, that they constitute a form of torture and that they violate article 30 of the Lebanese law on medical ethics, which prohibits doctors from engaging in harmful practices. A Helem activist described the contingent character of their activism:

\footnotetext{
The only tangible policy change that we were able to create, which is temporary because it's nonbinding, so it might change at any point, is getting the syndicate of doctors to ban rectal exams and to get the Ministry of Justice to issue a memo, not a ruling, to the prosecuting general and heads of police bureaus and police stations saying that you are not allowed to do this test anymore. ${ }^{68}$
}

As part of this project of grounding the movement in the local environment, Helem strives to positively change the cultural values and norms of key policymakers, practitioners and the wider public in relation to the LGBTQI population. The criminalisation of non-normative sexuality in Lebanon is sustained by the framing of such acts as inherently unnatural. Lebanese sexual minorities are discursively constructed as deviant through language. In Lebanese Arabic, the traditional term for homosexuality is 'shaz', which translates into the pejorative expression of 'pervert/faggot'. As a Helem activist explained, the usage of 'shaz' generates a particular 'mindset of people using this word', which stymies their potentiality to accept the legitimacy of LGBTQI rights. Thus, "if you were saying I am a "pervert" - how can I get someone to listen to me?' ${ }^{69}$ The use of the 'shaz' descriptor has even been deployed in the past by the mainstream media in reports on the LGBTQI population.

LGBTQI activists contest these discursive and textual practices through a number of tactics. Helem have been instrumental to introducing the word 'mithli', which broadly 
translates into 'different from me', as an alternative to 'shaz'. While 'mithli' has as yet not completely replaced the 'shaz' descriptor it is now beginning to permeate public discourse. LGBTQI activists have achieved this change, in part, by cultivating relationships with a younger generation of broadcasters and media stakeholders sympathetic to the claims of LGBTQI and feminist activism. An LGBTQI activist explained the importance of change in language

The entire language has changed, even how we call homosexuals. In Arabic we would use verbs and adjectives that were very violent but after article after article, protest after protest people are becoming aware of the violence of these terms. ${ }^{70}$

Activists also work to get key policymakers to revise and challenge cultural norms and values of key policymakers. For example, as noted earlier, Law 534, criminalises homosexuality on the basis that it is supposedly 'unnatural'. A number of judges, however, have refused to apply 534 by arguing that conceptions of nature are essentially socio-cultural constructs, making it impossible to designate any behaviour categorically against human nature. In declaring the decision not to apply Law 534, a judge commented that what is understood as unnatural is closely connected to 'the mood of a society and its traditions', and that society can also accept new 'norms of nature'.

\section{Active Resistance}

Rather than simply align themselves with the objectives of international funders, many members of Lebanon's sexual minority movement tailor their activism to the local context of the state's sectarian institutions. As we have explored in the previous section, this activism entails operating through the state's informal institutions in order to deactivate processes that oppress the LGBTQI population. If this strategy is one of engagement with the state's 
informal sectarian institutions, a more radical and frictional generated by some activists is to challenge and dismantle the sectarian system. Thus many activists in the Lebanese LGBTQI movement link their campaign against homophobia with the wider fight to oppose the sectarian system

Naber and Zataari note that some activists view 'Lebanon's sectarian structure ... as a key site of struggle not only because it is divisive ... but also because it is patriarchal and requires compulsory heterosexuality'. ${ }^{71}$ This opposition to power-sharing is evident in the statements of movement activists. For one former Helem leader, a fundamental objective of the LGBTQI movement is 'fighting to end confessionalism of the political system'. ${ }^{72}$ Meem identified one of its major goals as 'resisting sectarianism,' since 'the biggest challenge to any form of social justice in Lebanon is the sectarian makeup of its society'. ${ }^{73}$ For a former Helem leader, homophobia is inextricably connected to the sectarian system. Since 'the attitude of Lebanese society toward homosexuality is linked with a social order that forces people into confessional identities ... where a secular and progressive alternative is presented, Lebanese society will not fail to accept or even embrace an organisation calling for the end of oppression based on sexual preference'. ${ }^{74}$

In identifying power-sharing as censoring non-heterosexuality, radical Lebanese activists oppose it. LGBTQI resistance, therefore, is articulated not through advancing 'a onedimensional liberal framework of 'gay rights,' ' but through rejecting a sectarian identity. ${ }^{75}$ LGBTQI activists align themselves with radical non-sectarian movements that call for political 'deconfessionalism', the abolition of the sectarian system. These movements represent the not insubstantial minority of Lebanese that intentionally challenge the exclusivist narratives of ethnic identity embedded into the consociational system. Such movements, including secularists, socialist, anarchist and feminist movements, represent individuals that disidentify from ethnic categories. 
As part of this project of conceptualising the effects of sectarianism, LGBTQI activists build links and networks with many non-sectarian groups in Lebanon. An LGBTQI activist explained the importance of understanding the intersectional dynamics of Lebanon's sectarian system, in which questions of sexuality are linked with other social identities:

\footnotetext{
if you want to look at the sectarian system, you have to look at from an intersectional perspective. You have to look at in terms of how it effects your social class, your economic class, your race, your ability, your sexuality and if you look at that you will see how the layers are created. ${ }^{76}$
}

Another activist noted how many activists from other non-sectarian movements - including those concerned with corruption, gender, human rights, and the protection of public spaces have become connected to LGBTQI activism. An LGBTQI activist noted:

\begin{abstract}
We now have a much wider movement which acknowledges the connections between things in the sectarian system. A lot of the people involved in protests against corruption have now become interested also in the feminist and LGBT movements. I think that they see these as all part of the same dynamic. The same people who are against rights for sexual minorities are the same people involved in sectarianism and corruption. ${ }^{77}$
\end{abstract}

Thus, Helem and other LGBTQI groups forge networks with a range of Lebanese non-sectarian movements, ranging from feminists, movements against corruption, racism, rights for migrant workers, labour movements, and movements protecting public spaces from privatising public space. For one activist, the LGBTQI movement has advanced an 'antisectarian, anti-racist, and anti-xenophobic position' ${ }^{78}$ A female activist has similarly written of how the LGBTQI movement engaged in a 'critique of systems of oppression, such as patriarchy, racism, sectarianism, heteronormativity, Zionism, classism, rather than using a legal framework for organizing' ${ }^{79}$ 
One particularly fruitful alliance was forged in recent years between the LGBTQI movement and 'Beirut Madinati' ('Beirut My City'), a political party that emerged to contest Beirut's 2016 municipal elections by advancing a deliberate non-sectarian political platform, which included support for LGBTQI rights. Although Beirut Madinati lost the election, it nevertheless gained more than a third of the overall vote and more than half of the vote in the middle-class districts of east Beirut. In response to the threat posed by new and liberal nonsectarian parties in east Beirut, one of the main sectarian parties, the Kataeb, subsequently became the first mainstream Lebanese party to endorse the decriminalisation of homosexuality.

A further way in which activists contest the sectarian system is by making sexual difference into a form of dissident public culture. The lesbian social movement Meem's statement of purpose captures this 'non-identitarian' spirit: 'We are the non-conforming sexual community of Lebanon: the lesbians, the bisexuals, the queer, the questioning women, the transgendered and transsexual men and women, the Muslims, the Christians, the Druze, the atheists and agnostics' ${ }^{80}$ Such politics, as Seidman notes, is a 'resistance to identity-based models of self and politics ... in a nation in which kin and sect impose enveloping and inflexible identities on all individuals'. ${ }^{81}$

This non-identitarian politics excludes, as one activist writes, pursuing a 'legal change/LBT rights discourse.' Meem instead adopted a strategy of relative or 'ambiguous invisibility,' which eschewed a policy of 'coming out' and protest politics and instead focused on the safety of members by providing a safe space for lesbians. ${ }^{82}$ Meem's resistance to 'patriarchy and sectarianism' began by creating a nonsectarian movement deliberately designed to transcend ethnic cleavages. In one document Meem explained that the movement's 'very existence as a diverse ... community - one of the rare few in Lebanon - is in itself a challenge to the sectarianism endemic in Lebanese society and politics'. ${ }^{83}$ Meem 
utilised the post-identity term 'queer' to situate their politics and they fostered 'alliances with local women's and human rights movements, with leftist political parties and progressive thinkers. ${ }^{84}$

One particular way in which activists advance non-identitarian resistance to the sectarian system is through the relationships of members. To freeze the balance of power between the main groups, Lebanon's sectarian system forbids marriage between members of different religious sects unless one of the partners converts to the other's religion. The existence of same-sex relationships that cross sectarian boundaries profoundly disturbs the ethnic mosaic in which individuals are assigned to monolithic and discrete communities. Naber and Zataari illuminate, in relation to Lebanon, that 'nonconformist sexuality challenges sectarianism, and there are more same-sex couples that come together across sectarian divides than heterosexual couples'. ${ }^{85}$ Yet, while LGBTQI activists view the movement as a challenge to political sectarianism, they also recognise that, in some ways, it can reproduce sectarian divisions.

A Helem activist noted:

The way that confessional politics works here is amazing, because sometimes it seeps into the LGBT community itself, much less so than the rest of the country ... you see a lot more bi-sectarian relationships among the community. However, you also notice that there are a lot of LGBT people with a heightened sense of confessional and religious belonging. They go to two churches, the gay bar and the actual church (interview September 2012).

\section{Conclusion}

Adequate protection of human rights is central to sustainable peace in postwar societies. The failure to ensure human rights for all individuals in such states undermines the promotion of political and economic participation and thus undercuts the three lynchpins of the liberal 
peace: rule of law, democratisation and free-markets. Yet, in many postwar states, public institutions, including governance forms, are purposely designed to give guarantees of rights to the main ethnic groups, a structure which has the corollary of excluding and negatively affecting the rights of non-ethnic groups, including sexual minorities.

At the same time, the spread of LGBTQI rights has become a core part of the global human rights movement and state and international aid and development agencies make protections for sexual minorities a key part of their work. These global human rights agencies sponsor local LGBTQI activists and movements in their struggle to achieve rights in societies where sexual minorities experience discrimination and persecution. Yet, rather than a topdown model of global rights diffusion spreading from the Global North to the Global South, global processes, as Tsing reminds us, can only be charged and enacted through practical encounters at the local level. ${ }^{86}$ 'For human rights ideas to be effective', notes Merry, 'they need to be translated into local terms and situated within local contexts of power and meaning, ${ }^{87}$

A number of scholars deploy the concept of 'friction' to capture the encounters between global and local actors and norms - between human rights policy or rhetoric and actual practice - which may not always generate predetermined, predictable and positive dynamics. Notions and practices concerning global human rights may be ill fitting and inappropriate for activists working on the ground and who confront an array of complex dynamics. In response, local activists can act to reproduce, hybridise, and contest global rights norms, especially when these norms do not resonate with the local environment that activists work within. In this article I have analysed how these frictional dynamics operate in the context of postwar societies, particularly in places where sectarian power-sharing systems guarantee the rights of the respective ethnic groups perceived to have been involved in the conflict. While such power-sharing systems have short-term benefits by incentivising 
belligerent groups to abandon violence for guarantees of democratic representation, in the long-term they tend to institutionalise sectarian divisions and politics. More particularly, such sectarian institutions overlap and intersect with gender and sexuality to reproduce patriarchy and homophobia. These institutions are also often weak and dysfunctional meaning that there is little possibility of non-sectarian movements, such as the LGBTQI movement, gaining access to advance rights claims. In this constrained environment, the LGBTQI movement confronts a strategic dilemma - whether to 'upscale' activism by courting powerful international actors to use their leverage to promote LGBTQI rights in Lebanon or to 'downscale' by constructing modes of activism that are specifically designed to deal with the local character of the sectarian system. Rather than satisfactorily resolve this dilemma, Lebanese LGBTQI activist divide and disagree on what strategies to peruse leaving a rather fragmented movement that has increasingly undergone a process of NGOisation. While international donors and development agencies are undoubtedly important partners in the promotion of LGBTQI rights in places where sexual minorities constitute vulnerable communities, these actors need to be more understanding of the local context in which LGBTQI activism takes place. This sensitivity requires greater awareness of how postwar sectarian institutions impact on sexual minorities and the way in which activists work through informal institutions to effect change, which is often contingent and easily reversible.

Disputes over gay and lesbian rights occupy a central place on both national and international agendas in recent years. There is, however, little research on LGBTQI rights in divided societies emerging from intrastate conflict. Further work is urgently required within the field of peacebuilding and transitional justice studies to the capture the multiple dimensional relationship connecting contemporary conflict, peace processes and sexuality. More specifically, such research could examine whether contemporary conflict is 
characterised by particular forms of violence against sexual minorities and what protections and rights should be afforded to LGBTQI populations in postwar peace agreements. 


\begin{abstract}
References
${ }^{1}$ United Nations General Assembly, 'Discriminatory Laws and Practices and Acts of Violence against Individuals Based on their Sexual Orientation and Gender Identity', Report of the United Nations High Commissioner for Human Rights, 2011,
\end{abstract}

http://www.ohchr.org/documents/issues/discrimination/a.hrc.19.41_english.pdf (accessed June 2017), 3.

${ }^{2}$ Office of the High Commission for Human Rights (OHCHR), 'Ending Violence and Discrimination Against Lesbian, Gay, Bisexual, transgender and Intersex People. United Nations: Office of the High Commission for Human Rights, 2015,

http://www.ohchr.org/Documents/Issues/Discrimination/Joint_LGBTI_Statement_ENG.PDF (accessed May 2017).

${ }^{3}$ Susie Jolly, "'Queering" Development: Exploring the Links between Same-sex Sexualities, Gender, and

Development, Gender \& Development 8, no.1 (2000): 78-88.

${ }^{4}$ Anna Lowenhaupt Tsing, Friction: An Ethnography of Global Connection (Princeton, NJL Princeton University Press, 2004).

${ }^{5}$ Sally Merry, Human Rights and Gender Violence: Translating International Law into Local Justice (Chicago, IL: University of Chicago Press, 2006).

${ }^{6}$ APPG, The UK's Stance on International Breaches of LGBT rights (Westminster: APPG, 2016).

${ }^{7}$ Annika Björkdahl and Kristine Höglund, 'Precarious Peacebuilding: Friction in Global-local Encounters', Peacebuilding 1 no.3 (2013): 292.

${ }^{8}$ Merry, Human Rights and Gender Violence.

${ }^{9}$ Tsing, Friction, 4.

${ }^{10}$ Björkdahl and Höglund, 'Precarious Peacebuilding', 289.

${ }^{11}$ John Nagle and Mary-Alice Clancy, 'Constructing a Shared Public Identity in Ethnonationally Divided Societies: Comparing Consociational and Transformationist Perspectives', Nations and Nationalism, 18 no.1 (2012): 78-97

${ }^{12}$ Bassel Salloukh, The Politics of Sectarianism in Postwar Lebanon (London: Pluto, 2015).

${ }^{13}$ John Nagle, 'Crafting Radical Opposition or Reproducing Homonormativity? Consociationalism and LGBT

Rights Activism in Lebanon', Journal of Human Rights, 17no. (2018): 75-88.

${ }^{14}$ John Nagle, Social Movements in Violently Divided Societies: Constructing Conflict and Peacebuilding (Abingdon: Routledge, 2016).

${ }^{15}$ Graeme Reid, 'The Double Threat for Gay Men in Syria', The Washington Post, 2014, https://www.washingtonpost.com/opinions/the-double-threat-for-gay-men-in-syria/2014/04/25/30117ee2-ca3a11e3-a75e-463587891b57_story.html?utm_term=.b574f88071c7 (accessed June 2017).

${ }_{16}$ Virginia M. Bouvier, Gender and the Role of Women in Colombia's Peace Process (New York: UN Women, 2016).

${ }^{17}$ Katherine Fobear, 'Queering Truth Commissions', Journal of Human Rights Practices 6, no. 1(2014): 51-68. Bernadette Hayes and John Nagle, 'Ethnonationalism and attitudes towards gay rights in Northern Ireland', Nations and Nationalism 22 no.1 (2016): 20-41.

${ }^{18}$ Elizabeth Picard, Lebanon: A Shattered Country (New York, NY: Holmes and Meir, 2002).

${ }^{19}$ International Center for Transitional Justice, 'Failing to deal with the past: What cost to Lebanon?', 2014, https://www.ictj.org/sites/default/files/ICTJ-Lebanon-Impunity-Report-2014.pdf. (accessed May 2018), 1.

${ }^{20}$ Fawwaz Traboulsi, A History of Modern Lebanon (London: Pluto, 2007), 38.

${ }^{21}$ John Nagle, 'Between Entrenchment, Reform and Transformation: Ethnicity and Lebanon's Consociational Democracy', Democratization, 23 no.7 (2016): 1144-61.

${ }^{22}$ Bassel Salloukh, 'The Limits of Electoral Engineering in Divided Societies: Elections in Postwar Lebanon', Canadian Journal of Political Science 39 no.3 (2006): 637-638.

${ }^{23}$ Melani Cammett, Compassionate Communalism: Welfare and Sectarianism in Lebanon (New York: Cornell University Press, 2014), 64.

${ }^{24}$ John Nagle, 'Beyond Ethnic Entrenchment or Amelioration: An Analysis of Non-Sectarian Social Movements and Lebanon's Consociationalism', Ethnic and Racial Studies, 41 no.7 (2018): 1370-1389.

${ }^{25}$ Hannes Baumann, 'Social Protest and the Political Economy of Sectarianism in Lebanon', Global Discourse 6 no.4 (2016): 3.

${ }^{26}$ Bassel Salloukh, 'The Architecture of Sectarianization in Lebanon', in Sectarianization: Mapping the New Politics of the Middle East, eds. N. Hashemi and D. Postel (Oxford: Oxford University Press, 2017), 225.

${ }^{27}$ John Nagle and Tamirace Fakhoury, 'Between Co-option and Radical Opposition: A Comparative Analysis of the Consequences of Liberal and Corporate Power-Sharing on Gender and LGBT Movements in Northern Ireland and Lebanon', Nationalism and Ethnic Politics, 18 no.1: 82-99. 
${ }^{28}$ Nadine Naber and Zeina Zataari, 'Reframing the War on Terror: Feminist and Lesbian, Gay, Bisexual, Transgender, and Queer (LGBTQ) Activism in the Context of the 2006 Israeli Invasion of Lebanon', Cultural Dynamics 26 no.1 (2014): 91-111.

${ }^{29}$ Nagle and Fakhoury, 'Between Co-option and Radical Opposition'.

30 'Helem' is the Arabic word for 'dream'.

${ }^{31}$ Helem, 'A Case Study of the First Legal, Above-Ground LGBT Organization in the MENA Region', https://www.moph.gov.lb/userfiles/files/Prevention/NationalAIDSControlProgram/Helem.pdf (accessed June 2018), 4.

${ }^{32}$ Interview, June 2015

${ }^{33}$ Makarem Ghassan, 'The story of Helem', Journal of Middle East Women's Studies, 7 no.3 (2011), 100.

${ }^{34}$ Gender and Sexuality Resource Center, Lebanese Attitudes Towards Sexualities and Gender Identities (Beirut: Arab Foundation for Freedoms and Equality, 2015), 7.

${ }^{35}$ Aidan McGarry and James Jasper, The Identity Dilemma: Social Movements and Collective Identity (Philadelphia: Temple University Press, 2015).

${ }^{36}$ Susan Hekman, 'Beyond Identity: Feminism, Identity and Identity Politics', Feminist Theory 1 no.3 (2000), 289-308.

${ }^{37}$ Interview, July 2014

${ }^{38}$ Sofian Merabet, (2014) Queer Beirut (Austin, TX: University of Texas Press, 2014), 113.

${ }^{39}$ Interview, July 2014.

${ }^{40}$ Interview, July 2014.

${ }^{41}$ Peter M Nardi, 'The Globalization of the Gay and Lesbian Socio-political Movement', Sociological Perspectives, 41 no.3, 571)

${ }^{42}$ Dennis Altman, Global Sex (Chicago, IL: Chicago University Press, 1994), 86-87.

${ }^{43}$ John Nagle, 'Sites of Social Centrality and Segregation: Lefebvre in Belfast, a "Divided City"', Antipode 41 no.2 (2009): 326-347.

${ }^{44}$ Phillip M. Ayoub, 'Contested Norms in New-adopter States: International Determinants of LGBT Rights

Legislation', European Journal of International Relations, 21 no.2 (2015): 293-322.

${ }^{45}$ Interview, October 2017

${ }^{46}$ Interview, June 2015

${ }^{47}$ Interview, June 2015

${ }^{48}$ Interview, October 2017

${ }^{49}$ Interview, October 2017

${ }^{50}$ Joseph Massad, 'The West and the Orientalism of Sexuality', 2009,

http://www.resetdoc.org/story/1530/translate/English (accessed June 2018).

${ }^{51}$ Interview, October 2017

${ }^{52}$ Interview, October 2017

${ }^{53}$ Interview, June 2015

${ }^{54}$ Interview, June 2015

${ }^{55}$ Meem, Arab Queer Women and Transgenders Confronting Diverse Religious Fundamentalisms: The Case of Meem in Lebanon (Meem: Beirut, 2010), 17

${ }^{56}$ Interview, June 2015

${ }^{57}$ Interview, June 2015

${ }^{58}$ Interview, June 2015

${ }^{59}$ Interview, June 2015

${ }^{60}$ Meem, Arab Queer Women, 17

${ }^{61}$ Interview, October 2017

${ }^{62}$ Interview July 2014

${ }^{63}$ Interview, July 2014

${ }^{64}$ Interview, June 2015

${ }^{65}$ Interview, October 2017

${ }^{66}$ Interview, July 2014

${ }^{67}$ Interview, July 2014

${ }^{68}$ Interview, June 2015

${ }^{69}$ Interview, October 2017

${ }^{70}$ Interview, October 2017

${ }^{71}$ Nadine Naber and Zeina Zataari, 'Reframing the War on Terror: Feminist and Lesbian, Gay, Bisexual, Transgender, and Queer (LGBTQ) Activism in the Context of the 2006 Israeli Invasion of Lebanon', Cultural Dynamics 26 no.1 (2014): 91-111. 
${ }^{72}$ Ghassan Makarem, 'The LGBT Struggle in Lebanon', Socialistworker, 2011, http://socialistworker.org/2011/02/02/lgbt-struggle-in-lebanon (accessed March 2015).

${ }^{73}$ Meem, Arab Queer Women, 17.

${ }^{74}$ Makarem, 'The Story of Helem', 100-101.

${ }^{75}$ Naber and Zataari, 'Reframing the War on Terror, 103.

${ }^{76}$ Interview, October 2017

${ }^{77}$ Interview, October 2017

${ }^{78}$ Ghassan, 'The story of Helem', 105.

${ }^{79}$ Sarah Hamdan, 'Becoming-Queer-Arab-activist: The case of Meem', Kohl: a Journal for Body and Gender Research, 1 no. 2 (2015), 72

${ }^{80}$ Meem, Arab Queer Women, 29.

${ }^{81}$ Seidman, 'The Politics of Cosmopolitan Beirut', 22.

${ }^{82}$ Hamdan, 'Becoming-Queer-Arab-activist'.

${ }^{83}$ Meem, Arab Queer Women, 9.

${ }^{84}$ Meem, Arab Queer Women.

${ }^{85}$ Naber and Zataari, 'Reframing the War on Terror', 101.

86 Tsing, Friction, 1.

${ }^{87}$ Merry, Human Rights and Gender Violence, 1. 